\title{
Diksi-Diksi Gender dalam Sajak-Sajak Dorothea: Kontra Hegemoni Dunia Penciptaan Kaum Lelaki
}

\author{
Rangga Asmara ${ }^{1}$, Widya Ratna Kusumaningrum ${ }^{2}$ \\ Universitas Tidar ${ }^{1,2}$ \\ asmara@untidar.ac.id ${ }^{1}$,kusumaningrum@untidar.ac.id ${ }^{2}$
}

\begin{abstract}
Abstrak
Dalam dua dekade terakhir ini, isu perempuan telah mendapat perhatian, terutama oleh orang-orang yang memandang dan menganggap perempuan dari konstruk dunia lelaki. Dalam lingkup sastra, permasalahan yang ada tidak terbatas pada keterlibatan perempuan dalam dunia penciptaan, kritik, dan sebagai penikmat saja. Namun, eskalasi penciptaan para penyair perempuan telah menunjukkan perlawanan atas superioritas kaum lelaki terhadap perempuan. Seks dan lembaga perkawinan yang selama ini menjadi simbol hegemoni lelaki telah menjadi sebuah dekonstruksi dan parodi. Objek material penelitian ini adalah kumpulan sajak Nikah Ilalang karya Dorothea Rosa Herliany. Pengumpulan data dilakukan dengan metode simak yang dikembangkan dengan teknik catat untuk menjaring data. Dalam menganalisis data, sajak-sajak Dorothea pertama-tama dibaca dengan cara heuristik. Langkah berikutnya, dilakukan pembacaan hermeneutik melalui "kacamata" semiotik dengan hipogram potensial dan aktualnya, sehingga menemukan model sebagai aktualisasi matriks.
\end{abstract}

Kata Kunci: sajak; Dorothea; gender; hegemoni lelaki

\begin{abstract}
In the last two decades, women's issues have been attracting public attention, particularly for those who see and study women from male world of construction. In the literature framework, the existing problems are not limited to the women's involvement in the creation, criticism, and as readers only. However, the growth of the creation of female poets has opposed to men's superiority towards women. The role of gender and institution of marriage, which have been the symbol of hegemonic masculinity, has become a deconstruction and parody. The aim of this study is to dismantle the gender dictions in the Dorothea's poem, which reflect the hegemonic masculinity. The object of this research is the poetry collections entitiled Nikah Ilalang' by Dorothea Rosa Herliany. Technique of data collection used was notetaking. In analyzing the data, Dorothea's poetries are studied by using heuristic and hermeneutic techniques. In using hermeneutic technique, this study used semiotic approach and potential/ actual hypogram in order to find a proper model as matrix actualization.
\end{abstract}

Keywords: rhymes; Dorothea; gender; hegemonic masculinity

\section{Pendahuluan}

Ideologi patriarki makin berkembang di masyarakat, tidak hanya bidang sosial, budaya, ekonomi, politik, tetapi juga dalam lingkup sastra (Damono, 1978:1). Praktik semacam ini diwariskan dari generasi ke generasi melalui berbagai instrumen: agama, sistem so- sial, ekonomi, kultural, dan hukum (Ruckdeschel, 2008). Jika yang demikian tidak lagi dianggap sebagai bentuk penindasan, maka praktik hegemoni telah melembaga (Zimmerman melalui Ritzer, 2008:414). Ketika lingkungan sosial dan budaya penuh praktik hegemoni suatu kelompok atas kelompok yang lain, maka hal itu akan terekam dalam karya sastra 
(Sunardi, 2007; Nurulhadi, 2011; Sungkar, 2011).

Karya sastra tidak lahir dalam situasi kekosongan sosial budaya (Teeuw 1980:11). Riffaterre (1978:23), juga menyatakan bahwa sebuah puisi/karya sastra merupakan respons atau jawaban terhadap teks-teks lain sebelumnya. Respons tersebut dapat berupa pertentangan atau penerusan tradisi dan dapat pula sekaligus (Culler, 1981:107).

Dalam khazanah sastra Indonesia tidak banyak penyair yang secara konsisten menyuarakan feminisme dalam sajak-sajak mereka, sebut saja Toeti Herati (Mimpi dan Pretensi), Dorothea Rosa Herliany (Nikah Ilalang, Kill The Radio/ Sebuah Radio Kumatikan, Nyanyian Gaduh, Para Pembunuh Waktu), dan Oka Rusmini (Patiwangi, Pandora).

Munculnya para penyair perempuan sebenarnya menunjukkan eskalasi perlawanan atas dominasi dan superioritas kaum lelaki terhadap perempuan, seks dan lembaga perkawinan. Kaum feminis pada umumnya beranggapan bahwa seks adalah simbol dominasi lelaki terhadap perempuan. Karena itu, dalam sajaksajak feminis, seks dan lembaga perkawinan menjadi yang paling “diserang” oleh kaum feminis, dalam arti didekonstruksikan, dijungkirbalikkan, dan diparodikan.

Barangkali di antara penyair karya-karya feminis itu, apa yang diungkapkan Dorothea melalui sajak-sajaknya merupakan sesuatu yang tidak diduga akan diucapkan oleh seorang perempaun Indonesia, bertentangan dengan stereotipe dan tradisi yang umum. Ia berani untuk berbicara tentang berbagai hal yang selama ini menjadi tabu: seksualitas, kemarahan, ketidakadilan, dan ungkapan-ungkapan yang telanjang tentang klaim budaya atas perempuan seolah ingin menggeser ideologi kontrafeminis yang berkembang saat ini.

Nikah Ilalang merupakan kumpulan sajak yang diterbitkan tahun 1995 dan dapat dikatakan sebagai kumpulan puisi yang unik. Keunikannya terutama ditunjukkan oleh judulnya, Nikah Ilalang. Dua kata ini, "nikah" dan "ilalang", secara semantis tidak berkaitan satu sama lain. Juduljudul puisi yang terkumpul di dalamnya menunjukkan hal yang senada. Sebagian besar bertajuk "nikah" yang disandingkan dengan kata benda yang tidak lazim mengikutinya, seperti "pisau”, “ilalang”, "sungai”, dan "perkampungan”.

Puisi yang dianalisis dalam penelitian ini antara lain Nikah Pisau, Nikah Rumputan, Nikah Sungai, Nikah Perkampungan, dan Nikah yang Terbaring, Metamorfose Kekosongan, Nikah Laut, dan Nikah Pelacur Tak Punya Tubuh. Penulis berusaha mengkaji sajak-sajak Dorothea tidak hanya secara formal saja, menganalisis fenomena-fenomena saja, melainkan juga mengemukakan nilai dan fungsi estetik puisi dan menghubungkannya dengan penilaian dan pemakanaan.

Ada banyak metode dan pendekatan dalam analisis teks sastra. Metode analisis yang dipilih dalam penelitian ini adalah analisis semiotika Riffaterre. Puisi, bagi Riffatere adalah suatu aktivitas bahasa, yang berbicara mengenai sesuatu hal dengan maksud sesuatu yang lain. Bahan yang digunakanpun berbeda dengan bahasa sehari-hari, istilah Riffaterre ungrammaticality (Riffaterre, 
1978:2). Perbedaan ini disebabkan oleh tiga hal, yaitu adanya pengubahan arti (displacing of meaning), perusakan arti (distorting of meaning), dan penciptaan arti (creating of meaning) dari arti bahasa sehari-hari.

Bahasa sehari-hari, menurut Riffaterre, bersifat mimetik dan karenanya membangun arti (meaning) yang beraneka, terpecah. Bahasa puisi bersifat semiotik dan karenanya membangun makna (singnificance) tunggal, memusat. Sebagai ungkapan bahasa, bahasa puisi dapat dipahami melalui konvensi bahasa. Pembacaan tahap pertama ini berdasar asumsi bahwa bahasa itu bersifat referensial sehingga diperlukan kompetensi linguistik. Akan tetapi, menurut Riffaterre, pemahaman melalui konvensi bahasa memahami makna puisi selanjutnya. Dari pembacaan heuristic yaitu pembacaan yang didasarkan pada konvensi bahasa, (Riffaterre, 1978:5). Dari pemahaman arti yang masih terpecah, pembacaan puisi harus bergerak lebih jauh untuk memperoleh kesatuan makna dari puisi itu, yaitu dengan pembacaan hermeneutik yang didasarkan pada konvensi sastra. Gerak pembacaan ini dimungkinkan dan sekaligus didorong oleh adanya "rintangan" dalam pembacaan yang pertama yang disebut ungrammaticality (Riffaterre, 1978:23; Faruk, 1996:25).

Memahami sajak-sajak Dorothea bagi Riffaterre sama dengan memahami kue donat (Riffaterre, 1978:13). Apa yang hadir secara tekstual itu adalah daging donat itu (larik-larik puisi). Yang tidak hadir adalah ruang kosong yang berbentuk bundar di tengah donat dan sekaligus menopang dan membentuk daging donat menjadi donat. Ruang kosong yang tidak ada secara tekstual itu tetapi menentukan terbentuknya puisi itu oleh Riffaterre (1978:5) disebut hipogram. Hipogram dibedakan menjadi dua macam, yaitu hipogram potensial yang terkandung dalam bahasa sehari-hari seperti presuposisi dan sistem deskriptif dan hipogram aktual yang berupa teks-teks yang sudah ada sebelumnya.

Ruang kosong berbentuk bundar yang menopang daging donat dan membuat donat menjadi donat itu sekaligus merupakan pusat makna puisi. Pusat makna puisi itu oleh Riffaterre (1978:6-12) disebut matriks. Sebagaimana hipogram, matriks ini tidak tampak dalam teks puisi. Riffaterre (1978:6) menyebut yang hadir di dalam teks adalah aktualisasnya, dan akutualisasi pertama dari matriks adalah model yang bisa berupa kata, frase, atau kalimat tertentu (Faruk, 1996:26). Ciri utama dari model itu adalah sifat puitisnya. Model adalah tanda (kata, frase, atau kalimat) yang puitis, dan sebuah tanda hanya akan puitis apabila mengacu kepada hipogram tertentu. Kesatuan tekstual puisi yang diturunkan dari matriks yang dikembangkan melalui model tersebut menurut Riffaterre (1978:6) merupakan sebuah struktur yang seringkali terdiri dari satuan-satuan beroposisi secara berpasangan. Hubungan antarsatuan itu bisa berupa ekvivalensi (kesepadanan).

\section{Pembacaan Heuristik}

Sebagai ungkapan bahasa, sajak-sajak Dorothea dapat dipahami melalui konvensi bahasa. Pembacaan tahap pertama ini berdasar asumsi bahwa bahasa itu bersifat referensial. Perulangan bunyi-bunyi atau suku kata yang menghasilkan 
Poetika : Jurnal Ilmu Sastra

Vol. VI No. 1 Juli 2018
DOI $10.22146 /$ poetika.34842

ISSN 2338-5383 (print) ; 2503-4642 (online) efek-efek artistik dapat terjadi baik secara disengaja maupun tidak disengaja. Dorothea banyak menggunakan bunyi yang berkaitan dengan lambang rasa. Lambang rasa berhubungan dengan suasana hati penyair. Demikian tampak pada puisi Nikah Pisan berikut.

\section{Nikah Pisau \\ aku sampai entah dimana. berputar-putar dalam labirin. perjalanan terpanjang tanpa peta. dan inilab warna gelap paling sempurna. Kuraba gang diantara sungai dan jurang. \\ ada jerit, serupa nyanyi. mungkin dari \\ mulutku sendiri. kudengar erangan, serupa \\ senandung. mungkin dari mulutku sendiri \\ tapi inilah daratan dengan keasingan paling sempurna: tububmu yang bertaburan ulatulat kuabaikan. sampai kurampungkan kenik- matan \\ sanggama. sebelum merampungkanmu juga: menikam \\ jantung dan merobek zakarmu, dalam segala Ngilu}

Puisi Nikah Pisan bunyi atau pola bunyi yang bersifat istimewa untuk mendapat efek puitis atau nilai seni misalnya, terdapat dalam bait pertama aliterasi $/ r /$ yang berturut-turut: berputar-putar, labirin, perjalanan, terpanjang. Begitu juga bait kedua ada aliterasi /r/ dan asonansi / i/: jerit, nyanyi, dari, sendiri. Vokal /i/ terasa ringan, tinggi, dan kecil dapat melukiskan suasana hati yang ringan dan riang. Untuk mendapatkan nilai seni, Dorothea juga mengulang kata mulutku dan sendiri. Pada bait ketiga puisi $\mathrm{Ni}$ kah Pisan di atas juga menggunakan aliterasi / b/: kuabaikan, bertaburan, tubuhmu. Bunyi konsonan /b/ yang berat mendominasi dan digunakan sebagai simbolik bunyi.

\section{Nikah Rumputan \\ Telah lusub gaun pengantin: lepas rendanya. Sebab bunga liar yang esok bakal kupetik, Tak tumbub juga. \\ Bagaimana aku bisa menunggu dengan setia}

Bait pertama juga terlihat ada asonansi /a/: rendanya, bunga, juga, bagaimana, bisa, setia. Bunyi Vokal / a/ terasa berat dan rendah. Bunyi-bunyi yang berat tersebut untuk melukiskan perasaan sedih, gundah, dan murung.

\section{Nikah Sungai engkaubawakan aku bungabunga. di sini pasir, semak dan lumut melulu. kadang bauan busuk dan babkan bangkaibangkai. kepiting tak menyisib menyambutku \\ aku rebah di tanah basah. mengan- dung \\ racun dan beranak peradaban kering nurani}

Puisi berikutnya berjudul Nikah Sungai. Kata ulang tampak dalam petikan tersebut: bungabunga, bangkaibangkai. Pada bait kedua terdapat aliterasi /h/: rebah, di tanah, basah.

Dalam sajak-sajaknya, Dorothea juga mempergunakan cara pengucapan yang sama. Cara itu adalah penyimpangan ejaan yang tampaknya dilakukan dengan sengaja. Penyimpangan yang disengaja itu membimbing kita ke arah penafsiran tertentu (Damono, 1994). Berbeda dengan pendapat Damono, Sumarjdo dan Saini (1997) mengatakan bahwa, Dorothea bisa menaklukkan kesuburan imajinasinya ke dalam bangun sajak, meskipun tema yang ia pilih adalah tema-tema zaman dan perasaan halus. Namun, ia mampu mendisiplinkan dirinya 
menggiring imajinasinya ke dalam sebuah peristiwa konkrit yang unik dan satu-satunya. Rampan (1986) melihat sajak-sajak Dorothea tampaknya dituangkan dalam irama emosi dan sadar akan kemampuan puitiknya.

Struktur sajak-sajak Nikah Ilalang adalah struktur yang membangun sebuah ironi kehidupan perempuan. Ironi kehidupan ini antara lain dijelamakan oleh kondisi perempuan yang kontradiktif dan gaya ucap yang bebas dari tata aturan ejaan (berimplikasi pada kebebasan) yang digunakan untuk mengungkap "nikah", sesuatu yang demikian mengikat. Gaya ucap yang bebas dari aturan ejaan tampak pada peniadaan penggunaan huruf kapital (kecuali pada judul sajak), penggabungan dua atau lebih kata ke dalam satu kesatuan ucapan, serta penggunaan tanda titik sebagai tanda koma.

\section{Pembacaan Hermeneutik}

Pembacaan hermeneutik juga disebut pembacaan retroaktif (Riffaterre, 1978:6), yaitu pembacaan yang diharapkan memperoleh satuan makna puisi. Puisi, dalam hal ini dipahami sebagai satuan yang bersifat struktural sehingga pembacaan hermeneutik juga dilakukan secara struktural, yaitu bergerak secara bolak-balik dari bagian ke keseluruhan dan kembali ke bagian dan seterusnya. Karena puisi dipahami sebagai donat, yang mengandung ruang yang kosong di tengahnya yaitu matriks, maka dalam pembacaan hermeneutik pun memperhatikan hal-hal yang tidak tampak secara tekstual.

Dalam kumpulan sajak Nikah Ilalang ada objek-objek yang diceritakan: nikah, pisau, ila- lang, sungai, perkampungan, dan yang terbaring. Dalam judul-judul sajak tersebut pelaku atau subjek aku atau kau sebagai persona yang melakukan pernikahan. Pada Nikah Ilalang, engkau adalah subjek yang menikahi ilalang. Pada Nikah Perkampungan, aku adalah subjek yang menikah dengan rumah-rumah kardus, dunia yang gelisah, dan jaman yang sekarat minta susu. Sementara itu, pada Pengantin yang Terbaring, dua subjek yang menikah adalah aku dan kau.

Subjek berjenis kelamin perempuan ini memberikan praanggapan adanya konsep ideologi yang melekat padanya karena fungsi reproduksinya. Secara simbolik, aku pada sajak-sajak Nikah Ilalang dicitrakan sebagai perempuan dewasa. Ukuran kedewasaan aku dapat dilihat melalui statusnya. yang telah atau tengah melakukan pernikahan. Dalam Nikah Sungai dikemukakan dengan tanda-tanda lain yang tidak saling berhubungan, seperti "aku rebah di tanah basah, mengandung racun dan beranak peradaban kering nurani”

Aku adalah penderita karena menceritakan peristiwa yang dialami. Dalam Nikah Pisau aku bercerita tentang perjalanan hingga pada suatu tempat yang tidak jelas (asing). Dalam Nikah Sungai, aku mengandung racun dan beranak peradaban kering nurani. Dalam Nikah Perkampungan, aku mengawini rumah-rumah kardus. Dalam Pengantin yang Terbaring, aku mabuk bercumbu dengan pikiran sendiri. Berdasar atas tanda -tanda yang muncul yaitu tanda-tanda keperempuanan maka aku adalah perempuan, konkritnya adalah Dorothea si penyair. Ironi juga dijelmakan melalui penonjolan perempuan sebagai pribadi, dengan posisinya sebagai pencerita dan 
penggunaan kata ganti orang pertama tunggal, aku yang dilatari dengan setting dunia luar rumah.

Melalui sajak-sajaknya, Dorothea nampaknya juga berusaha mendobrak pemahaman-pemahaman yang merugikan posisi perempuan dalam perkawinan. Ia jelas mencari posisi tawar yang nyaman bagi kedua pihak. Hal ini tampak dalam penggalan sajaknya yang berjudul Nikah Sungai.

Di mana ruangyang kausediakan buatku?

Buat percintaan mahadahsyat.

Buat pertempuran tak usaiusai.

Nafsu yang senantiasa membuabkan kebencian dan bencana.

Pernikahan adalab peleburan,

langit dan laut yang terjaring jalajala,

perkawinan yang sempurna!

Tetapi barangkali, peleburan tetaplah sesuatu yang mengadaada, yang mungkin hanya menjanjikan keranda: Mempelai itu berjalan di atas tububtubuh terkulai.

Menuju rumah pengantin, sebuah gubuk dengan tiang tulang,

Dan rumbai-rumbai mayat, di seberang sungai mati,

Menuju ranjang bulan madu - sebuab keranda yang sunyi

Dan akbirnya: maka aku pun ingin memahat batu itu.

Bertabuntabun akbirnya kucipta nisan

Dalam sajak tersebut terdapat pengertian yang seolah-olah, ada sebuah kemarahan dan pemberontakan oleh sang pengantin. Kata memahat mengandung arti melakukan perbuatan yang terpatri lama. Kata nisan menyimbolkan kematian. Jadi, melalui bait terakhir mengandung pengertian sang pengantin ingin melakukan pemberontakan.

Hal serupa juga bisa dilihat dalam penggalan sajaknya yang berjudul Nikah Pisau yang sebagian sajaknya berbunyi:

Tapi inilah daratan dengan keasingan paling sempurna:Tububmu yang bertaburan ulatulat, kuabaikan. Sampai kurampungkan kenikmatan senggama. Sebelum merampungkanmu juga: Menikam jantung dan merobek zakarmu, dalam segala ngilu.

Dalam potongan bait tersebut mengandung pengertian, ingin mengadakan perlawanan. Hal ini terlihat melalui diksi yang digunakan. Pilihan katanya secara mimetis merupakan kata-kata yang kasar. Kata yang digunakan seperti merobek zakarmu dalam realitasnya tidak biasa dilakukan oleh seorang perempuan, kecuali memang sengaja dilakukan sebagai bentuk kemarahan dan pemberontakan. Dengan demikian, pada satu sisi perempuan menerima penderitaannya itu sebagai takdir yang harus dijalaninya. Di sisi lain, perempuan pun menolaknya.

\section{Hipogram Potensial}

Hipogram potensial adalah segala bentuk implikasi dari makna kebahasaan, baik yang berupa presuposisi, makna-makna konotatif yang sudah dianggap umum, dan sebagainya (Riffaterre, 1978:12). Puisi, bagi Riffatere adalah suatu aktivitas bahasa yang berbicara mengenai sesuatu hal dengan maksud sesuatu yang lain. Satuan terkecil berupa fonem. Satuan fonem berupa suku kata dan kata. Kata bergabung menjadi kelompok kata, kalimat, alinea, bait, bab, dan seluruh cerita. Semua itu merupakan satuan arti.

\section{Bahasa dalam sajak-sajak Dorothea,} menurut Riffaterre, bersifat mimetik dan karenan- 
ya membangun arti (meaning) yang beraneka, terpecah. Bahan yang digunakanpun berbeda, dengan diksi "laki-laki", istilah Riffaterre ungrammaticality (Riffaterre, 1978:2). Perbedaan ini disebabkan oleh tiga hal, yaitu adanya pengubahan arti (displacing of meaning), perusakan arti (distorting of meaning), dan penciptaan arti (creating of meaning) dari arti bahasa sehari-hari.

Secara mimesis dapat dikemukakan bahwa satuan-satuan arti dalam sajak-sajak Dorothea menunjukkan adanya keterpecahan makna. Pada dasarnya, pernikahan adalah pelembagaan atas kesepakatan untuk hidup bersama antara laki-laki dan perempuan. Pernikahan adalah pengukuhan, deklarasi, dan pengumuman yang bersifat sosial. Karenanya, orang-orang yang sudah menikah diberi status yang berbeda oleh masyarakat. Pembedaan status itulah yang lalu menciptakan perbedaan perilaku, kepantasan-ketidakpantasan, hak-hak dan juga kewajiban-kewajiban sosial. Seorang istri, misalnya, akan dinilai buruk ketika pulang larut malam. Seorang suami, dianggap punya kewajiban utama mencari nafkah untuk istri dan anaknya. Tentu saja, implikasi dari status menikah ini dapat berbeda-beda dari kelompok masyarakat yang satu dengan lainnya. Hal ini dapat dimengerti karena pada kata "nikah" secara mimesis mengandung pengertian adanya pengaturan yang disahkan antara laki-laki dan perempuan. Dalam hal ini kedudukan laki-laki dan perempuan dalam keadaan sejajar, samasama ingin bersatu. Dengan demikian, "nikah" yang secara mimesis membayangkan adanya penyatuan dua subjek, laki-laki dan perempuan tidak teraktualisasikan secara jelas dalam keseluruhan sajak.

Pisau memiliki pengertian pada sesuatu yang mengancam dan membahayakan karena tajam, pisau dapat melukai penggunanya, dengan demikian paduan antara nikah dan pisau menjadi beroposisi atau kontradiktif.

Paduan nikah dan sungai juga kontradiktif. Sungai adalah aliran air yang sangat bermanfaat bagi kehidupan. Namun sungai juga menjadi tempat pembuangan binatang-binatang kotor dengan demikian sungai merujuk pada sesuatu yang mengancam dan membahayakan. Perkampungan adalah tanda yang berimplikasi pada pemberitaan karena merujuk pada tempat-tempat pemukiman padat, kumuh, dan berpenghasilan rendah. Perkampungan menyiratkan kemiskinan, dan kemiskinan menjadi pangkal penderitaan.

Dengan demikian kebahagian beroposisi dengan penderitaan. Pisau, ilalang, sungai, dan perkampungan dalam paduannya dengan nikah semuanya merujuk pada sesuatu yang kontradiktif. Pisau dan sungai adalah metafora bagi sesuatu yang mengancam dan membahayakan. Ilalang adalah metafora bagi sesuatu yang mendominasi atau cenderung mendominasi. Perkampuangan adalah metafora dari penderitaan.

Dalam sajak-sajak Dorothea Rosa Herliany, makna dan kesan pernikahan yang terbayang sebagai sesuatu yang "paling indah dan kudus" tidak akan didapati. Kita akan berjumpa dengan gambaran pernikahan yang mengerikan, angkuh, egois, tidak wajar, dan sesekali murahan. Bahkan, beberapa sajaknya adalah pemberontakan yang garang atas pernikahan. Sebagai contoh: 
ketika menikabimu, tak kusebut keinginan setia.

Jauh sebelum itu, Dorothea juga sudah mempertanyakan kesetiaan dalam pernikahan pada sajaknya yang berjudul Nikah Rumputan.

\section{Telah lusub gaun pengantin: lepas rendanya.} Sebab bunga liar yang esok bakal kupetik, Tak tumbuh juga.

Bagaimana aku bisa menunggu dengan setia Ia memikirkan pasangannya:

Sedang bangkubangku telah berlumut.

Nafasmu mendekapkan cemas kesangsian, Selain mempertanyakan diri sebagi subyek dalam sajaknya:

Sedang sunyi membiarkan rebab menggesek rumputan di batinku

Tampaknya, ketegangan dan kegelisahan yang terjadi dalam sajak-sajak Dorothea berkisar pada bagaimana diri sebagai individu yang otonom dan merdeka harus meleburkan diri dalam identitas baru (keluarga). Ini persoalan kebebasan, untuk sebagian orang, pernikahan memang dianggap menjadi bencana yang mengancam keutuhan eksistensi diri yang tentu saja, ini memang beralasan.

Permasalahan lain yang seringkali terjadi selepas pernikahan adalah pembagian wilayah kekuasaan antara suami dan istri. Perempuan sebagai istri menjadi termarjinalkan karena hanya berada dalam wilayah domestik, apalagi dalam masyarakat patriarkal. Perempuan terjebak begitu memasuki pintu perkawinan akibat struktur dan tata nilai dalam masyarakat yang memaksanya demikian. Eksistensi dirinya diukur berdasarkan kemampuan mengelola dapur, merawat anak, dan melayani suami. Dalam kultur masyarakat tertentu, misalnya masyarakat Jawa, isteri yang baik adalah yang tunduk dan menurut pada suami. Seorang suami adalah kepala keluarga, dan karenanya suami memimpin, istri dipimpin.

Pengantin dalam sajak Nikah yang Terbaring adalah sebutaan bagi orang yang sedang menikah. Pengantin dapat merujuk pada laki-laki dan perempuan. Saat menjadi pengantin adalah saat yang membahagiakan, namun demikian dalam puisi ini dikontraskan dengan pilihan kata "terbaring".

Subjek demikian menjadi kode bagi satu dunia berkonstruk patriarkhi. Konstruk patriarkhi adalah konstruk yang menempatkan laki-laki sebagai self (yang satu) dan perempuan sebagai other (yang lain). Dalam penyatuan demikian, perempuan menjadi pihak "pengantin" yang terbaring atau berada dalam keadaan lemah tidak berdaya.

Dapat dipastikan persona aku atau engkau adalah persona yang menyadari bahwa penyatuannya dengan dunia berkonstruk patriarkhi membuatnya menderita atau sesuatu yang mengikatkan diri pada penderitaan. Sebagaimana dikemukakan pada larik "dengan sadar aku kawini rumah-rumah kardus, dengan sadar, aku kawini dunia yang gelisah". Meskipun demikian, perempuan tidak kuasa dan tidak berdaya untuk mengingkarinya, seperti terlihat pada larik "aku rebah di tanah basah".

\section{Hipogram Aktual, Model, dan Matriks}

Puisi itu merupakan "pesan" penulis kepada pembaca tentang sastra, yaitu sesuatu mempunyai kekuatan. Hal ini karena sesuatu itu ulet, tidak mudah patah. Sesuatu itu merupakan hasil dari buah dari orang yang suka berolah cipta, 
rasa, dan karsa. Oleh karena itu, buah perilaku cipta, rasa, dan karsa itu bertahan sampai bertahun-tahun dan dijadikan pedoman.

Sebaliknya, sesuatu yang bersifat fisik (bangunan/wadag) itu mudah patah (rusak) sehingga bersifat sementara sungguhpun memberikan kesenangan (bermanfaat) lahir. Akan tetapi, bangunan dunia imajiner ini belum sepenuhnya utuh dan belum membentuk satu kesatuan makna yang menjadi pusatnya yang dalam teori Riffaterre disebut matriks.

Matriks teridentifikasi dalam bentuk model karena model merupakan aktualisasi pertama darinya. Model biasanya dapat dirunut melalui kata, frase, atau kalimat tertentu tetapi yang bersifat puitis sehingga berbeda dengan kata, frasa, atau kalimat yang lain. Sebuah tanda dikatakan puitis jika tanda itu bersifat hipogramatik. Melalui hipogram potensial, pembacaan hermeneutik ini telah berhasil mendapatkan kesatuan dunia imajiner puisi, yang dalam pembacaan heuristik terkesan beraneka ragam, terpecah.

Apabila dilihat secara sekilas sajak-sajak Dorothea menggambarkan sebuah perjuangan menggeser kultus dan mitos dunia perempuan. Penyair perempuan pun dapat membuat puisi dengan diksi laki-laki. Anggapan umum tentang klaim terhadap perempuan yang lebih teliti dan lebih hati-hati daripada laki-laki, dirusak total dalam sajak-sajak Dorothea. Puisi Dorothea juga merupakan representasi pemberontakan, baik terhadap patriarki dalam pengucapan puisi maupun terhadap tradisi basa-basi dalam sastra Indonesia yang tidak berani menyebut seks.
Lakoff (1975:4) mengatakan bahwa ujaran perempuan menunjukkan perbedaan dengan ujaran yang digunakan oleh laki-laki. Perbedaan ini secara linguistik berlangsung sejak kecil melalui proses pembelajaran bahasa yang deskriminatif. Bahasa dalam bentuk ujaran yang keras atau kasar adalah bahasa yang khas digunakan oleh laki-laki. Sebaliknya ketika perempuan menggunakan ujaran yang cenderung keras atau kasar, maka masyarakat akan menstereotipkan sebagai perempuan kasar, tidak santun, atau tidak feminim. Secara empiris, diksi pada sajak-sajak Dorothea merupakan diksi yang lazim digunakan oleh laki-laki.

Citra wanita dalam sajak-sajak Dorothea bukan sekadar menonjolkan aspek dunia wanita saja, melainkan dunia wanita yang dikemas sedemikian rupa melalui sarana diksi laki-laki dan beberapa dekonstruksi tradisi puisi di Indonesia. Dengan cara ini, Dorothea berusaha untuk mensejajarkan jenis kelamin wanita dalam dunia puisi, dan hendak menunjukkan superioritas wanita dihadapan lelaki. Wanita dicitrakan sebagai makhluk individu yang beraspek fisik dan psikologis, dan sebagai makhluk sosial yang beraspek keluarga dan masyarakat. Sebagai makhluk individu, wanita dicitrakan sebagai makhluk yang lemah, tidak berdaya, dan memiliki peran yang tidak membahagiakan.

Dalam sajak-sajak Dorothea, citra wanita dalam masyarakat berkaitan erat dengan citra diri dan proses sosialisasi, akibatnya karena faktor itu maka terciptalah citra budaya yang menimbulkan nilai rendah bagi wanita. Citra sosial dalam sajaksajak Dorothea menggambarkan citra wanita yang berideologi gender. Wanita melihat dan merasakan 
bahwa ada superioritas pria; akta kekuasaan pria terhadap wanita dalam berbagai dimensi kehidupan. Ironisnya, meskipun wanita menyadari citra diri yang demikian, namun ia menerima hal tersebut sebagai sesuatu yang sudah semestinya terjadi.

Sajak-sajak dalam Nikah Ilalang mengajak pembaca berkontemplasi terhadap kesan pernikahan yang bernuansa pemberontakan yang garang. Jauh sebelum itu, Dorothea sudah mempertanyakan kesetiaan dalam pernikahan pada sajaknya yang berjudul Nikah Rumputan, ketika menikahimu, tak kusebut keinginan setia. Secara kultural banyak lahir mitos yang mengajarkan bahwa perempuan harus taat dan setia pada lelaki, namun Dorothea mendekonstruksi dan membuat parodi terhadap kultus ini. Untunglah Riffaterre juga menyatakan bahwa sebuah tanda dalam puisi haruslah dipertimbangkan tidak hanya dalam hubungannya dengan hipogramatik nontekstual, melainkan juga dalam hubungannya dengan matriks keseluruhan teks (Faruk, 1996:33).

Model dari sajak Nikah Ilalang adalah dominasi laki-laki terhadap perempuan dan keberanian perempuan untuk menggeser dominasi laki-laki. Oleh karena itu, matriks dari sajak Nikah Ilalang adalah ketidakseimbangan antara kehidupan laki-laki dan perempuan melalui pilihan kata (diksi) dan citra yang dibangun. Hal tersebut dapat dibuktikan dengan pilihan kata yang cenderung maskulinitas (keras, kasar, dan menjijikkan). Pada Nikah Pisau terlihat pada, sampai kurampungkan kenikmatan senggama, menikam jantung, merobek zakarmu, tubuhmu yang bertaburan ulat-ulat, kuabaikan.

Kedua tanda itu sebenarnya merupakan dua sisi dari "satu mata uang" yang sama. Tanda pertama adalah sisi negatif sementara itu tanda kedua merupakan sisi positif. Kedua sisi itu sebenarnya saling melengkapi sehingga menjadi hidup. Hasil dari negasi itu berupa ajakan yang mengarah kepada terbentuknya kebiasaan manusia sebagai makhluk di hadapan hukum Tuhan untuk berbuat sesuatu dengan dilandasi sikap yang mengutamakan olah kejiwaan (cipta, rasa, dan karsa).

Tanda kedua merupakan alat sehingga bersifat sementara, serba menarik. Melalui pemahaman demikian, tampaklah bahwa kedua sisi model itu sebenarnya berasal dari matriks yang sama, yaitu kemauan atau kehendak (will). Bahwa, dengan negasi (pengingkaran) orang dapat membangun sebuah dunia baru yang merupakan dictum dari logika kultural. Matriks ini penting karena berakar dan reproduksi dari wacana religius ketimuran yang masih terus hidup.

Ada dua tanda matriks yang teridentifikasi dalam bentuk model dalam sajak-sajak Dorothea. Dalam kumpulan sajak Dorothea ada beberapa kosa kata yang berorientasi pada kelamin. Demikian tampak dalam sajak yang berjudul Nikah Pisau, "merobek zakarmu". Pilihan kata tersebut mengandung sebuah ambiguitas. Dalam susunan sewajarnya kata merobek apabila dihubungkan dengan alat kelamin adalah merobek vagina bukan zakar, tetapi telah didekonstruksi 
atau diparodikan oleh Dorothea, justru yang dirobek adalah zakar yang tidak lain adalah alat kelamin laki-laki.

Dalam sajak yang berjudul Metamorfose Kekosongan terdapat larik Kau ledakkan aku dengan zakarmu. Secara semiotik petikan sajak tersebut dapat dimaknai, perempuan merasa tersakiti atau dihancurkan oleh seorang laki-laki, karena menunjukkan adanya kata zakar. Zakar lebih dominan daripada vagina.

Dalam sebagian sajaknya Dorothea juga menggunakan kosa kata maskulinitas. Misalnya kata: pilot, tentara, nelayan, masinis, dan petani. Kata-kata tersebut merupakan pekerjaan yang identik dilakukan oleh pekerjaan laki-laki. Dalam sajaknya yang berjudul Nikah Laut, Dorothea menggunaklan kata nelayan. Garamgaram itu kau peras dari keringat nelayan. Penggunaan peras juga menunjukkan adanya emosi dan kekesalan, karena kata tersebut cenderung kasar. Dalam sajak Nikah Sungai juga terdapat kosa kata yang bersifat melawan misalnya:

Dimana ruang yang kau sediakan buatku?

Buat percintaan mahadabsyat. Buat pertempuran tak usaiusai.

Nafsu yang senantiasa membuabkan

\section{kebencian dan bencana.}

Dalam bait tersebut ditemukan adanya pemakaian kosa kata pertempuran. Bukankah pertempuran selama ini menggambarkan adanya perlawanan. Hal tersebut juga terlihat dalam bait terakhir yang bunyinya,

Nafsu yang senantiasa membuabkan kebencian dan bencana.
Terlihat dari kata yang digunakan membuahkan kebencian dan bencana menunjukkan adanya perasan benci dan menganggap apa yang dilakukan seorang laki-laki tersebut mengakibatkan bencana terhadap dirinya.

Dalam sajak lain juga terdapat kosa kata yang mencerminkan adanya upaya menggeser ideologi kontrafeminis, yaitu pada sajak Nikah Pelacur Tak Punya Tubuh diduga juga sebagai upaya perjuangan seorang wanita, sebagaimana tersirat dalam judul, seorang pelacur untuk mencapai ke jenjang pernikahan dibutuhkan usaha -usaha yang luar biasa dalam dunia nyata. Secara sosiologis, seorang pelacur adalah wanita yang dipinggirkan. Sebaliknya perkawinan adalah lembaga sosiologis yang disakralkan, itulah sebabnya usaha seorang pelacur ke jenjang perkawinan adalah suatu bentuk perjuangan.

\section{Kesimpulan}

Model dari sajak Nikah Ilalang adalah dominasi laki-laki terhadap perempuan dan keberanian perempuan untuk menggeser dominasi laki-laki. Matriks dari sajak Nikah Ilalang adalah ketidakseimbangan antara kehidupan laki-laki dan perempuan melalui pilihan kata (diksi) dan citra yang dibangun. Struktur sajak-sajak Nikah Ilalang adalah struktur yang membangun sebuah ironi kehidupan perempuan. Ironi kehidupan yang dijelamakan oleh kondisi perempuan yang kontradiktif dan gaya ucap yang bebas dari konvensi bahasa. Puisi Dorothea merepresentasikan pemberontakan, baik terhadap patriarki dalam pengucapan, penciptaan, maupun terhadap tradisi sastra Indonesia (puisi) yang tidak berani menyebut seks. 
Poetika : Jurnal Ilmu Sastra

Vol. VI No. 1 Juli 2018
DOI $10.22146 /$ poetika.34842

ISSN 2338-5383 (print) ; 2503-4642 (online)

\section{Daftar Pustaka}

Culler, Jonathan. 1981. The Pursuit of Sign. London: Methuen \& Co.Ltd.

Damono, Sapardi Djoko. 1978. Sosiologi Sastra Sebuah Pengantar Ringkas. Jakarta: Pusat Pembinaan dan Pengembangan Bahasa Depdikbud.

Faruk.1996. "Aku dalam Semiotika Riffaterre, Semiotika Riffaterre dalam Aku." Humaniora no. III, 1996:24-33. https:// journal.ugm.ac.id/jurnal-humaniora/article/ view/1942/1746.

Lakoff, Robin. 1975. Language and Woman's Place. New York: Harper and Row.

Nurulhady, Eta Farmacelia. 2011. "The Strugle of the Other: Maggie Tulliver in George Eliot's the Mill on the Floss." Kajian Sastra vol.34, No.1:69-81. https:// ejournal.undip.ac.id/ index.php/kajiansastra/article/view/ 2669.

Pradopo, Rachmat Djoko. 1993. Pengkajian Puisi. Yogyakarta: Gadjah Mada University Press.

Rampan, Korrie Layun. 1986. Jejak Langkah Sastra Indonesia. Ende-Flores: Nusa Indah.

Ratna, Nyoman Kutha. 2004. Teori, Metode, dan Teknik Penelitian Sastra dari Strukturalisme hingga Postrukturalisme. Yogyakarta: Pustaka Pelajar.

Riffaterre, Michael. 1978. Semiotics of Poetry. Bloomington \& London: Indiana University Press.

Ritzer, George. 1996. Modern Sociological Theory, $4^{\text {th }}$ (eds.). New York: The McGrawHill.

Rosa Herliany, Dorothea. 1995. Kumpulan Sajak Nikah Ilalang. Yogyakarta: Yayasan Pustaka Utama.

Ruckdeschel, Kerstin. 2008. "Attitudes towards Gender Roles and Fertility Behaviour" dalam C Hohn et al. People, Population Change and Policies, vol 2: Demographic Knowledge-Gender -Ageing. Springer Science and Bussiness Media B.V.

Sumardjo, Jakob dan Saini, K.M. 1997. Apresiasi Kesusastraan. Jakarta: PT Gramedia Pustaka
Utama.

Sunardi. 2007. "Diferensiasi Linguistis Berdasarkan Gender dalam Teks Sastra Inggris." Linguistisa vol.14, No.27. https://ojs.unud.ac.id/ index.php/linguistika/article/view/269.

Sungkar, Lubna. 2011. "Citra Perempuan dalam Clochette dan Madame Baptise Karya Guy de Maupassant.” Kajian Sastra vol.34, No.1:82-94. bttp:/ / eprints.undip.ac.id/26372/.

Teeuw, A. 1980. Sastra Indonesia Baru. Ende Flores: Nusa Indah.

Wellek, Rene dan Austin Warren. 1995. Teori Kesusastraan. Jakarta: PT Gramedia. 